\title{
The Impact of Agriculture and Home Economics in National Development
}

\author{
Ikeogu Dennis 0. \\ Nwokolo C.K.C \\ Chidolue Ifeyinwa B. \\ School of Agriculture and Home Economics \\ Federal College of Education (Technical), Umunze-Anambra State, Nigeria
}

\section{Doi:10.5901/jesr.2013.v3n5p65}

\begin{abstract}
Effective solutions to ecological problems must be based upon recognition of the diversity that exists in rural settings around the world (Slayter-Thomas et al. 1991). Prescriptive action must also recognize the very significant role of women in managing natural resources in a nation's development with appropriate target conservation messages and techniques. Thus, family is an important income-earning and consuming decision-making unit in all developing country societies, and it should be a focal point for efforts to put adequate food within reach of all people (Seltzer 1980). Ipso facto, there is clearly a need for an integrated, holistic approach to training and extension, and to expand curricular content in a way that relates the local environment to the global community, and that relates macro and micro levels of interaction.
\end{abstract}

\section{Introduction}

Land, water and forests are the primary resources of home economics and agricultural production, and are the resources essential to maintain human life and well-being. The use of these resources must be balanced with conservations to sustain national development, and to avoid environmental degradation and losses both in home economics and agricultural productivity. These natural resource bases provide many benefits to different groups of people in both urban and rural areas. The environment that sustains development is used by people in many ways. Farms and forests supply nations with a wide range of important raw materials: timber, wood, pulp, minerals, leather, and foodstuffs, which are further processed into manufactured goods such as lumber, Paper, pharmaceuticals, footwear and flour. These raw materials and finished products are important to the economic security of the country, and to the food security of its citizens. Natural resources also provide rural people with food, medicines, game, honey, gums and resins, condiments and other goods that are exchanged or used for secondary processing, and contribute greatly to rural subsistence. On the other hand, home economics has, at different times, emphasized training in needlework, cookery, the management of servants, the preparation of medicines, and food preservation; such instruction was once given mainly in the home and from a practical rather than a scientific standpoint. The causes of environmental change and degradation are very complex, and stem from different levels - from global and national, to individual farms and households (Commonwealth Secretariat 1992). Demographic pressures have changed the way that people use land, water and forests, and have contributed to a widespread deterioration in the condition and productivity of these resources. Past economic development policies, international lending, and 
development assistance programmes have contributed in some cases to environmental mismanagement. In addition, destructive land use practices of the past are resulting in present-day reduced productivity of croplands, forests, pastures, and fisheries, and in increased poverty and hunger (Brown et al., 1993).

\section{Rural households and the Environment}

Families are the fundamental building blocks of social and economic development (Firebaugh 1991). Families as rural households are keys to understanding environmental changes in developing countries, as they are the immediate users and managers of rural ecosystems at the subsistence level. Rural households are those closest to the environment and have the potential to play the primary roles in conserving and protecting land, water, and forests. Farmers, (women) are the direct and everyday users of land and water, and are those most in need of new technologies, information, and services that can increase their productivity and conserve scarce resources. It is essential that decision- makers recognize that women are at the center of the development process and that the improvement of their status and the extent to which they are free to make decisions affecting their lives and that of their families will be crucial in determining future population growth rates (Dankelman and Davidson 1991). That notwithstanding, women's meager access to agricultural training/ home economics programs in no way reflects the overwhelming percentage of time that they spend in agricultural labor (Verghese, in Dankelman and Davidson 1989). Nor do home economics curricula include environmental conservation topics and methods appropriate to rural households as they manage natural resources. Sequel to World Conservation Strategy, an action plan for governments to develop their own national conservation policies, provides useful definition conservation:

"Conservation is a process to be applied cross-sectorally, not an activity sector in its own right. In the case of sectors directly responsible for the management of living resources, conservation is that aspect of management which ensures that utilization is sustainable and which safeguards the ecological processes and diversity essential for the maintenance of the resources concerned" (Dankelman and Davidson 1989).

Living resource conservation has three specific objectives:

- To maintain essential ecological processes and life support systems on which human survival and development depend;

- To preserve biological diversity (the range of biological and genetic material);

- To ensure the sustainable utilization of species and ecosystems (Dankelman and Davidson 1989).

The family represents one of the major ways that human populations organize and adapt to meet goals, needs and communicate values in diverse environmental circumstances (Bubolz 1991). Significantly, women's activities involving the socialization of children in the space of the household provide an excellent opportunity for teaching environmental values, attitudes and behavior to children (Steady 1993). As the building block of rural communities, family is the nexus for the transfer of social and economic behavior patterns, survival skills, and environmental values across the generations. E.g., Women in Tanzania learn from their grandmothers that trees bring rain, and that cutting large blocks of trees will have a deleterious effect on rainfall. Young girls in India learn to tend livestock from their maternal relatives. In Sudan, Ethiopia, Mozambique, and other countries undergoing long-term stress, indigenous knowledge of survival strategies of various family members are passed on through the generations. In Malawi, family members plant saplings at the death of a relative or friend, preserving and protecting indigenous species on sacred lands. Agricultural skills, home economics, conservation techniques, and many other forms of indigenous technical knowledge are handed down from one generation to the next. . Economic and political factors, such as the privatization of common property resources, and inappropriate land use 
policies, can negatively impact rural people. Broad demographic changes, such as population growth, resettlement, migration, urbanization, and movements of refugees can also impact rural communities. These pressures frequently change the land-person ratio in an area and place additional pressure on the resource base. People are sometimes forced into shorter-term land use practices that are not sustainable. Additionally, newcomers may bring with them land use practices from their area of origin that are not necessarily to the new environment in which they have resettled.

Rural households often face difficult trade-offs in decision-making about natural resources, as they seek to balance the conflicting demands of managing the surrounding environment with the economic survival of the family. For example, privatization of land may reduce the amount of land that is available to a family for grazing. A decision must be made whether to maintain the same number of animals in poor condition on the smaller area, or to destruct the herd, which may result in a loss of household income, savings, security, and status.

To support households in facing these trade-offs, innovative new technologies and investment must be generated so as to relieve pressure on the natural resource base. Under conditions of food insecurity in low income countries, new technologies for crop and livestock management cannot be chosen exclusively for their compatibility with the environment. They must also allow for higher incomes for the rural poor (FAO 1993f). There may also be difficult environmental trade-offs in balancing industrial and urban growth with sustaining the natural resource endowments available to households in rural areas. Urbanization and industrialization may contribute to deforestation through increased demand for timber for construction or charcoal, to watershed degradation downstream through the deposition of urban and industrial wastes, and pollution through the concentration of wastes and pollutants. The family unit is the organizing unit for the exchange of one valuable resource. Human labour, as family members assume different economic and productive roles within the household, the marketplace, the formal and informal workforce. Yet rural households are often fragmented either economically or spatially. When a child does not reside with both parents, the household cannot be considered a closed economic system (IFPRI 1992). Divorce, remarriage, single parenthood, rising number of female-headed households, teenage motherhood, and single-sex unions all are a part of these changing family forms and structures (Firebaugh 1991). In that case, women everywhere have greatest responsibility for the economic support of their families, and for the maintenance of local ecosystems. The migration of men to urban areas to seek employment leaves women as de facto heads of households in many countries. The absence of men from the family and community disrupts the normal social structure (Rodda 1991), and places additional burdens on women for the day-to-day maintenance of their families. Women make up a slight majority of the world's population and a visible majority of the rural poor (Dankelman and Davidson 1989). A monumental share of rural households is comprised of women and their dependents, which tend to be disproportionately represented among poor, refugee and landless households. In Botswana, over one-third of all households are permanently or temporarily headed by women (Rodda 1991). A large portion of the world's homeless about 1,000 million people are women. And of the world's ten million refugees, women and children make up in some areas 90 per cent (Celik in Dankelman and Davidson 1989). Looking broadly at resource use, all family members are users of natural resources. Ultimately, we need to understand the ways in which changes in the environment and in community structures affect both men and women across all social categories (Thomas-Slayter et al. 1991; Ofosu-Amaah 1993).

\section{Development in Sustainability at the Household Level}

There is a growing recognition that even well-planned development policies and programs sometimes have negative environmental impacts that are undetected until their impact is severe (Eckman 1993). ). There is also considerable interest on the part of development planners in fostering sustainable solutions to rural poverty and resource degradation problems. The concept of 
sustainability has come to be regarded as both a goal in development assistance programs, and as an approach to development policies (Eckman 1993). FAO defines sustainability as:

"The management and conservation of the natural resource loose, and the reorientation of technological and institutional in such as manner as to ensure the attainment and continued satisfaction of human needs for present and future generations. Such sustainable development fin the agriculture, forestry and fisheries sectors) conserves land, water, plant and animal genetic resources, is environmentally non-degrading, technically appropriate, economically viable, and socially acceptable" (FAO 1988).

For rural households, sustainability has both environmental and socioeconomic elements, and one element cannot be sustainable without the other. Perhaps most importantly, extension services and home economics curricula have generally not supported or reached rural households that are struggling with the effects of environmental degradation. Hunger and malnutrition are closely linked with both environmental un-sustainability and inadequate socioeconomic development, and are not simply problems of inadequate agricultural productivity or supply. Improving the potential for environmental sustainability will likely have a positive impact on the socioeconomic sustainability of rural households. Rural households in developing countries have the greatest potential to be the prime force for generating agricultural productivity and rural viability (FAO 1991w). Improving the access of rural households to environmental information and to conservation-oriented technologies can enable them to better manage and care for the natural resources upon which they depend. Rethinking development in sustainability terms also means linking the global and local use of natural resources. Where many households are using natural resources in an unsustainable way, the associated costs and problems can be exported to neighboring villages and towns, downstream dwellers, or to distant continents through airborne pollutants or through the movement of water. For example, pollution from burning fossil fuels, smoke from sycophancies and wind erosion of African soils contribute to global climate change and to atmospheric pollution over distant continents. The transfer of industrial pollutants from developed to developing countries and of nuclear wastes in oceans will bring costs to future generations when clean-ups are needed. The challenge is to foster the sustainable use of natural resources in ways that can be economically viable to rural populations, and that limit the export of environmental problems to others.

\section{Challenges of Educational Needs at the Family Level}

As the environmental and economic contexts facing rural households change, so do the educational needs of family members. Better access to education can improve the ability of farmers to use natural resources more productively, and to diversify their income sources away from dependence upon natural resources alone (Mink 1993). Thus, educational needs will expand skills, technologies, and information in environmental management and rehabilitation, resource conservation, waste and pollution management, energy, and other relevant areas. The strategic fiasco that emerges is that the majority of youth in the labor force is illiterate or semiliterate, living in rural areas, and is struggling to make a living from agriculture, home economic and other rural occupations. In the developing world, $80 \%$ of young people have serious deficiencies in resources or preparation for adult life, and at least 50\% lack both (Ahmed in Seltzer, 1983). The monumental costs of limited educational opportunities becomes more significant when coupled with the realization that women and girls are among the least educated, yet are the group that produces the bulk of agricultural harvests at the subsistence level implementation of home economic activities. Home economics activities and Agricultural output are reduced when women have less access than men to inputs and support services, such as extension. If women were to apply the same volume and quality of inputs as men, their gross value of agricultural output would increase by about $22 \%$. Given that women in Africa produce three-fourths of the region's food, total food production in Africa could 
increase by 10 to $15 \%$ (World Bank 1992). The education of young women is particularly important because of the extensive range of women's resource management. Improving their income earning possibilities increases the opportunity costs of raising children and the incentives to have smaller families, while providing the means to improve the health and educational prospects of children they do have; both developments have clear environmental benefits (Mink 1993). The economic and social returns to education for women and girls are substantial, and are on the whole greater than for men. In the recent World Bank investigations, it shown that by improving training and education for women, a country can reduce poverty, improve productivity, ease population pressure, and offer its children a better future (Herz, Subbarao, Habib and Raney 1991; Subbarao and Raney 1993).

\section{Home Economics in a Changing World}

Home economics has assumed new directions and responsibilities in recent years, and has reclaimed its early roots that rest squarely in the field of ecology. In the early 20th century home economics diverged from the development of ecology and other related disciplines, such as biology and anthropology. Home economics became centered on aesthetic and functional relationships primarily in the context of western middle-class households. There was an emphasis on household technologies, and on traditional values related to home, motherhood, and the ideology that these were women's primary vocation (Bubolz 1991; FAO 1991w). Hitherto, home economics has developed a reputation for "stitch and stir." As the model that was in part transferred from western countries to developing nations in the post-independence period as part of development assistance efforts.

According to Seltzer (1980), it is not that aspects of home economics have not been and are not now involved to some extent in development activities. Home economics has a long and successful history in development, much more limited but paralleling in many ways what agriculture has been doing in research, technical assistance, education and training. However, the theoretical rationale and scope of home economics has moved far beyond the conventional image of sewing and cooking, and has returned to its roots once again to embrace the ecological and economic relationships of rural families: the household and its near environment. New conceptual frameworks have been developed based upon ecological models and human/environmental interactions (Deacon and Firebaugh 1988; FAO 1990g; Bubolz 1991; FAO 1992f; Bubolz and Sontag 1993). The new model of home economics focuses on mutually sustaining interactions that link people and environments, and on the decisions that families make to creatively adapt and foster human development (Bubolz 1991). Hence, this reflects evolving reorientation of home economics toward broader ecological and environmental relationships for development at large.

\section{Impacts of Home Economics to Developing Countries}

Home economics is a crossroads in developing countries. The reorientation of home economics is a response to concerns about the relevancy of home economics programs in developing countries in serving the rural household (FAO 1991w). This traditionally female-dominated profession, commonly credited as serving a predominantly female clientele, needs to utilize its capabilities more effectively in national development. In particular, there is a need to broaden agricultural education curricula to better serve the diverse rural household production needs of all family members through extension services (FAO 1991w).

There is a growing literature on women and development which points out the dangers of assuming that economic growth benefits men and women equally within rural households in developing countries. It is now common knowledge that certain approaches to development have failed to bring benefits to all members of rural households (Commonwealth Secretariat 1992). ). In a community setting, the context is usually less structured, and in addition to preparing for and 
teaching youth and adults, a home economics educator may spend more time in assessing needs, developing programs, recruiting learners, and consulting with learners who have specific problems to solve (Seltzer 1985). Pankhurst (1992) states that development can even be detrimental to women and children especially in their roles as resource managers and rural economic actors. The vast majority of agricultural and forestry extensionists in Africa are male, with the number of women extensionists averaging only $3 \%$. This represents a serious limitation in the extent to which women farmers are in contact with outside advice on agricultural technologies (Commonwealth Secretariat 1992) with regard to agricultural production, processing, preservation, storage, exchange, and environmental management. On that note, Women's meager access to agricultural training programs in no way reflects the overwhelming percentage of time that they spend in agricultural labor (Dankelman and Davidson 1989).

Alongside the general neglect of women farmers, the extension services which they do receive are often restrictively stereotyped. Women are often regarded as gardeners and are provided with extension services in small-scale poultry or vegetable production rather than staple crops or large livestock; even through they are often also responsible for the latter. In addition, cash crops are normally introduced to men, rather than women, which in turn tends to marginalize the women from the financial benefits of this production (Commonwealth Secretariat 1992).

\section{Conclusion}

Every country pays a high price for environmental un-sustainability and degradation. The challenge is to foster development that is technically sound, culturally acceptable, and economically viable. Rural families are the key to the sustainable use the natural resources. Development planners and educators should seek to reconcile the resources, needs, and realities of rural households with the requirements of national development strategies. The challenge for educators is to not only enable rural families to use resources at their disposable in a sustainable manner, but also to transfer knowledge and skills that can increase their productivity and improve their well-being. Home economics has the potential to treat rural households in an ecosystem perspective, recognizing that households are both consumers and producers of renewable and nonrenewable natural resources.

\section{Recommendation}

\subsection{Enabling Rural Households to Overcome Constraints}

From the concept, it is clear that rural households (women) face a number of interlinked constraints that reduce their productivity and ability to use natural resources sustainably in nation's development effectively. These constraints summarized below should be looked considered to enhance development at large:

1. Limited access to extension services, credit, and services, technologies and information.

2. Insecure tenure.

3. Inadequate skills and incentives on the part of service providers to effectively reach rural households.

4. Uneven involvement of women in decision making.

5. Declining natural resource base and environmental degradation.

6. Geographical and physical isolations and sometimes limited contact with other farmers and extensionists.

7. Poor nutritional status and physical condition of family members, which constrains their productivity and well-being.

At the household level, strategies should seek to:

1. Avoid the unsustainable use of natural resources, and avoid environmental harm and degradation. 
2. Empower households especially women, in the political and decision-making process.

3. Expose women and girls to broader educational curricula, beginning with basic literacy and innumeracy skills.

4. Encourage the formation and empowerment of women's groups and other community groups that can take economic and environmental actions to benefit themselves.

5. Enable rural households to create and build assets that contribute to their economic wellbeing, such as savings, tree plantings, and other assets with real value to households.

6. Expose rural households to extension messages and technologies that can reduce waste, increase productivity and incomes, and save time and energy.

7. Improve the general physical well-being of family members.

\section{References}

Ahmed, I. (1985). ed. Technology and Rural Women: Conceptual and Empirical Issues. London, George Allen \& Unwin, P383

Brown, L. R. et al (1993). State of the World 1993. New York, Worldwatch Institute, W. W. Norton, P268 Brown, L. R et al (1994). State of the World 1994. New York, Worldwatch Institute, W. W. Norton, P265

Bubolz, M. M. (1991). Reflections on Human Ecology Past, Present \& Future. Paper Presented at the College of Human Ecology Spring Meeting, May 31 1991, Michigan State University, P45

Bubolz, M. M. \& Sontag, M.S. (1993). Human Ecology Theory. In Sourcebook of Family Theories and Methods, Boss, P.G, Doherty, W.J, LaRossa, R. Schumm, W.R., \& Steinmetz, S.K., ed.s. Plenum Press, New York, P419-446.

Cernea, M. (1981). Land Tenure Systems and Social Implications of Forestry Development Programs. Washington, World Bank, P35

Chambers, R. (1983). Rural Development: Putting the Last First. London, Longman, P246

Cocoyoc Mexico, (1974). Declaration. Patterns of Resource Use, Environment and Development Strategies.

Commonwealth Secretariat. (1992). Women, Conservation and Agriculture: A Manual for Trainers. London, Commonwealth Secretariat Women and Development Programme, P204

Consortium for International Crop Protection (CICP) (1985). Training Program for Pesticide Users Trainer's Manual. Berkeley (California, U.S.A.), United States Agency for International Development, P333

Cooperation in Development, Inc. (CODEL) (1985). Environmentally Sound Small-Scale Agricultural Projects. New York, CODEL, P138

Cunningham, T., Kinahan, J., Marsh, A., Stuart-Williams, V., Hubbard, D., Kreike, \& Seely, M. Oshanas: Sustaining People, Environment, and Development in Central Owambo, Namibia Namibia, SIDA. P58

Dani, A. \& Campbell, J. D. (1986.) Sustaining Upland Resources: People's Participation in Watershed Management. ICIMOD Occasional Paper No. 3. Kathmandu, ICIMOD, P121

Dankelman, I. \& Davidson, J. (1989). Women and Environment in the Third World: Alliance for the Future. London, Earthscan, P210

Eckman, K. (1993) Using Indicators of Unsustainability in Development Programs. In Impact Assessment Bulletin. Vol. 2 No. 3. P 275-287.

Elson, D. Rome, (1990). Some Issues Regarding Women's Roles in the Management of Family Resources for the Achievement of Household Food Security and Nutrition, by Nutrition Consultants' Report Series No. 83. P44

FAO. Improving Agricultural Extension Work With Rural Women: An Instructional Unit for the Preparation of Extension Workers. Rome.n.d.(a). P52

FAO. Report on Rural Youth Activities. A Response to General Assembly resolution 44/59. Rome, n.d. (b). P14

FAO Special Action Programme: Sustainable Development of Rural Households. Rome, n.d. (c). P4

FAO. Rome, (1987). Agriculture: Toward 2000. Economic and Social Development Series No. 23. Rome, 1981(a). P134

FAO. Rome, (1987). Restoring the Balance: Women and Forest Resources. P32 
Firebaugh, F. M. (1991). Families in Transition: A Global Perspective. In Journal of Home Economics 83:3 P44-50.

Mink, S. D. (1993). Poverty, Population and the Environment. Washington, D.C., World Bank, World Bank Discussion Paper P189. 40

Pankhurst, H. (1992.) Gender, Development and Identity: An Ethiopian Study. London, Zed Books, P216. Rodda, A. (1991). Women and the Environment. London: Zed Books Ltd. P180

Steady, F. C. (1993). Women, Shelter and the Environment. In Environmental Values 2: P163-76.

Thomas-Slayter, B. P., Rocheleau, D., Shields, M. D.,\& Rojas, M. (1991) Concepts and Issues Linking Gender, Natural Resources Management, and Sustainable Development: Concepts and Issues Paper Summary. ECOGEN (Clark University and Virginia Polytechnic Institute and State University), P12

World Bank. (1992).Raising the Productivity of Women Farmers in Sub-Saharan Africa In WIDLINE No. 6, Washington, D. C., The World Bank. P1-2. 